\title{
日本応用糖質科学会維持会員 \\ Support Corporate \\ Member of the Japanese Society of Applied Glycoscience
}

$(2016.1)$

アサヒグループホールディングス(株研究所

Asahi Group Holdings Ltd.

味の素ゼネラルフーヅ(株商品開発研究所

Ajinomoto General Foods, Inc., Research \& Development

(株) ADEKA

ADEKA CORPORATION

天野エンザイム(株)岐阜研究所

Amano Enzyme Inc., Gifu R \& D Center

(株アンデルセン・パン生活文化研究所

Andersen Institute of Bread and Life Co., Ltd.

上野製薬(株)

Ueno Fine Chemicals Industry Ltd.

エイチビィアイ株

HBI Enzymes Inc.

江崎グリコ(株)

Ezaki Glico Co., Ltd.

越後製菓(株)総合研究所

Echigo Seika Co., Ltd., Research Institute

MC フードスペシャリティーズ(株)

MC Food Specialties Inc.

塩水港精糖(株)

Ensuiko Sugar Refining Co., Ltd.

王子コーンスターチ(株)開発研究所

Oji Cornstarch Co., Ltd.

\section{大里研究所}

Osato Research Institute

(株オホーツク網走

Okhotsk Abashiri Corporation

花王(株)

Kao Corporation

加藤化学(株

Kato Kagaku Co., Ltd.

上川北部農協合理化澱粉工場

Kamikawahokubu Nokyo Gorika Starch Factory

キリン(株)

KIRIN COMPANY, Ltd.

清里町農協清里でん粉工場

Kiyosato Agricultural Co-operatives, Kiyosato Starch Plant

熊本製粉(株)

Kumamoto Flour Milling Co., Ltd.
群栄化学工業(株)

Gun Ei Chemical Industry Co., Ltd.

合同酒精(株)酵素医薬品研究所

Godo Shusei Co., Ltd.

小清水町農協澱粉工場

Koshimizu Town Agricultural Cooperative Association, Potato Starch Factory

サンエイ糖化(株)素材開発部

San-Ei Sucrochemical Co., Ltd., Merchandise Development

三和澱粉工業(株)

Sanwa Cornstarch Co., Ltd.

羊蹄連澱粉農協連

JA Youtei, Youtei Starch Factory

(株) J-オイルミルズ

J-Oil Mills. Inc.

士幌町農業協同組合

Shihoro Agricultural Cooperative Association

斜里町農業協同組合中斜里澱粉工場

Shari Agricultural Cooperative Association, Naka-Shari Starch Factory

上越スターチ(株)

Joetsu Starch Co., Ltd.

昭和産業(株)

Showa Sangyo Co., Ltd.

新日本化学工業(株)

Shin Nihon Chemical Co., Ltd.

神野でんぷん工場(株)

Jinno Potato Starch Co., Ltd.

(一財)杉山産業化学研究所

Sugiyama Chemical \& Industrial Laboratory

(株)瀬野鉄工所

SENO Machinery. Co., Ltd.

全国農業協同組合連合会園芸農産部

National Federation of Agricultural Co-operative Associations, Horticulture \& Farm Produce Department

宝酒造(株)

Takara Shuzo Co., Ltd.

竹之内穀類産業(株)

Takenouchi Barley Processing Co., Ltd.

ダニスコジャパン(株)

Danisco Japan Ltd. 
千葉製粉(株)

Chiba Flour Milling Co., Ltd.

中部化工建設(株)

Chubu Kakou Kensetu Co., Ltd

東部十勝農産加工農業協同組合連合会

The Eastern Part of Tokachi Agro-manufacturing and Agriculture Co-operative Society Federation

\section{東北化学薬品(株)}

Tohoku Chemical Co., Ltd.

\section{ナガセケムテックス(株)}

Nagase ChemteX Corporation

\section{日澱化学(株)}

Nippon Starch Chemical Co., Ltd.

(株)ニチレイフーズ研究開発部

Nichirei Foods Co., Research \& Development Division

(株)日清製粉グループ本社 R \& D ・ 品質管理本部

Nisshin Seifun Group Inc., Research and Development Quality Assurance Division

日本コーンスターチ(株)

Japan Corn Starch Co., Ltd.

\section{日本食品化工(株)}

Nihon Shokuhin Kako Co., Ltd.

日本水産(株)東京イノベーションセンター中央研究所 Nippon Suisan Kaisha, Ltd., Central Research Laboratory

日本スターチ・糖化工業会

Japan Starch \& Sweeteners Industry Association

日本製粉(株)中央研究所

Nippon Flour Mills Co., Ltd., Central Laboratory

日本甜菜製糖(株)総合研究所

Nippon Beet Sugar Mfg., Co., Ltd., Research Center

\section{日本澱粉工業(株)}

Nihon Starch Co., Ltd.

ノボザイムズジャパン(株)

Novozymes Japan Ltd.

(株)林原

Hayashibara Co., Ltd.

美幌地方農産加工農業協同組合連合会

Bihoro District, Agricultural Products Process, Agricultural Cooperative Association Union
富士産業(株)

Fuji-Sangyo Co., Ltd.

不二製油(株)つくば研究開発センター

Fuji Oil Co., Ltd., Tsukuba Research and Development Center

\section{フジ日本精糖(株)}

Fuji Nihon Seito Corporation

物産フードサイエンス(株)

B Food Science Co., Ltd.

(株)ブルボン

Bourbon Corporation

\section{北斗工機(株)}

Hokuto Kohki Engineering Co., Ltd.

ホクレン農業協同組合連合会でんぷん課

Hokuren Federation of Agricultural Cooperatives

北海道澱粉工業協会

Hokkaido Starch Industry Society

松谷化学工業(株)

Matsutani Chemical Industry, Co., Ltd.

三菱商事フードテック(株)食材開発研究センター

Mitsubishi Shoji Foodtech Co., Ltd., Center for Technological Development \& Application

南十勝農産加工農業協同組合連合会

Minami-Tokachi Rationalized Potato Starch Factory

(株)明治研究本部研究企画部

Meiji Co., Ltd.

森下仁丹(株)研究開発本部開発部

Morishita Jintan Co., Ltd.

森永製菓(株)研究所

Morinaga \& Co., Ltd., Research Institute

(株)ヤクル本社中央研究所

Yakult Central Institute for Microbiological Research

山崎製パン(株)中央研究所

Yamazaki Baking Co., Ltd., R \& D Division

雪印メグミルク(株)

Megmilk Snow Brand Co., Ltd. 